\title{
Re-defining Slovenian Touristic Regions
}

\section{Anton GosaR, Koper/Capodistria*}

with 8 figures and 2 tables in the text

\section{Content}

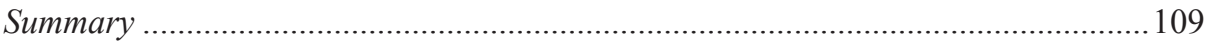

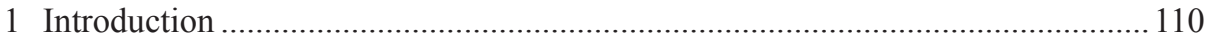

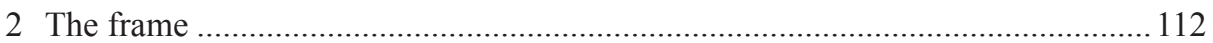

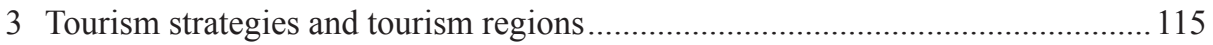

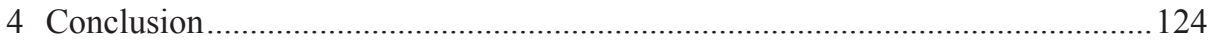

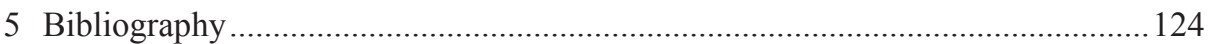

\section{Summary}

Twenty years ago, the post-Socialist transition and civil war in wider parts of Yugoslavia resulted in a widespread discussion on future tourism development and priorities. Slovenia has, since becoming a nation state, produced three tourism development strategies within which regional characters were bundled into diverse packages as tourism destinations. This paper examines the different ways Slovenia's territory was subdivided into selective units for tourism purposes. A wider socioeconomic and geo-political frame is observed as "tourism destination sub-regions" have been created. The physical landscape and character, and even the natural and cultural heritage elements, are playing an increasingly weak role in the definition of contemporary touristic regions. Tourism products promoting experience, entertainment and adventure as well as human-made attractions (including cultural events and events based on tradition) are the primar decision maker(s) in contemporary attempts to characterize specific macro-, meso- or micro- touristic regions.

* Anton Gosar, Prof. PhD., Department of Geography, Faculty of Humanities, University of Primorska, Titov trg 5, SI-6000 Koper/Capodistria, Slovenia; e-mail: anton.gosar@hs.upr.si 


\section{Introduction}

Tourism is a profit-making economy. According to ButLER's model of the lifecycle of a tourist destination (BUTLER \& ARAMBERI 2005), to overcome saturation and increase profits, a change in the supply part of the economy is needed. This could be achieved through several ways of action; one often-used method is related to the restructuring and to the re-vision of the geographic size or general features of the destination. The purpose of defining and re-defining geographic regions for tourism purposes - thus spacious areas/places of outstanding and/or unique attraction(s) - is therefore to characterize attractive area(s) and, as result, receive economic benefits by pinpointing and designating the site of the attraction. In such geographically wider or narrower (newly) defined regions the natural, historical, cultural and human resources, out of which one or more tourism products could be produced, are rediscovered and/ or re-invented. The new tourism products could than subsequently initiate a followup regionalization, where specific elements of nature, culture and/or human-made attractions become the core of promotion and subsequently profit.

Countries by themselves are "touristic destinations" and therewith touristic regions - as by their own territorial sovereignty, history, language, law, natural and cultural heritage, etc. The ITB Berlin [Internationale Tourismus Börse] and similar events in London, Milan [Milano], and elsewhere are events, where close to 200 countries world-wide express their own "destination" characters as nation states. They tend to draw attention by summarizing their own promotional characteristics in single sentences. Most often the country's natural, people's cultural, history's outstanding and citizen's warm attitudes/characters, as well as hidden (regional) treasures are addressed (Table 1). Promotional slogans tend to change in regard to politics and/or trends within the tourism supply and demand spheres. In the contemporary tourism world, traditional attractions related to history and outstanding places of nature and culture tend to be replaced by eco-awareness slogans, by experience/adventure provisions, or by friendly cultural endowment.

In this contribution we will concentrate on the strategy of tourism development and tourism regionalization in the Alps-Adriatic geographic area of Central and Southeast Europe, in particular on Slovenia. Tourism attractions of this area have been elaborated on maps and in discussion within the Atlas of Eastern and Southeastern Europe (JORDAN \& Schappelwein et al. 1999). The attempt to point out attractive places in a wider/ broader European area is rather unique. Namely, governments of nation-states and provinces/regions normally would stimulate and financially support scientific research and promotional materials which would concentrate on territory under their sovereignty. Now, countries and provinces of Central and South East Europe are digging into the material discussed above ("International Tourism Attractions in Central and Southeast 
Europe"), select relevant features, and form new promotional strategies which often result in revised strategies and/or (inner-state) touristic regions.

Table 1: Selection of tourism promotional nation-state advertising

\begin{tabular}{|r|l|l|}
\hline & \multicolumn{1}{|c|}{ Country } & \multicolumn{1}{c|}{ Slogan } \\
\hline 1 & Albania & A New Mediterranean \\
\hline 2 & Aruba & One Happy Island \\
\hline 3 & Belize & Mother Nature's Best Kept Secret \\
\hline 4 & Canada & Keep Exploring! \\
\hline 5 & Croatia & Mediterranean As it Once Was \\
\hline 6 & Ecuador & Life at its Purest \\
\hline 7 & Egypt & Where It All Begins \\
\hline 8 & France & Rendez-Vous En France \\
\hline 9 & Germany & Affordable Hospitality \\
\hline 10 & Grenada & Rhythms of Spice \\
\hline 11 & Hong Kong & Best Place, Best Taste \\
\hline 12 & Hungary & A Love for Live \\
\hline 13 & Italy & Much More \\
\hline 14 & Maldives & Sunny Side of Life \\
\hline 15 & Montenegro & Wild Beauty \\
\hline 16 & New Zealand & $100 \%$ Pure \\
\hline 17 & Slovakia & Little Big Country \\
\hline 18 & Slovenia & Sunny Side of the Alps \\
\hline 19 & Spain & Smile! You are in Spain \\
\hline 20 & Switzerland & Get Natural! \\
\hline
\end{tabular}

In the context of the discussion, we have registered that, within nation states, provinces tend to point out their outstanding features as well. In Slovenia's neighboring Austrian Carinthia [Kärnten], slogans tend to be extra- and introverted: "Carinthia - The Land of Waters", "Carinthia - Holidays spent with Friends", and - recently - "Carinthia - The Joy of Life"; in the neighboring Styria [Steiermark] two recent slogans were noticed: "Styria - The Green Hearth of Austria" and "Love Wonders through Styria". In the Italian Friuli-Venezia Giulia the official slogan points out the fact to "Be Guest of Unique People" and in the Croatian Istria [Istra] the slogans calls for "Mediterranean being a Perfect Holiday”. Therewith provinces (Länder, regione, županije) are already circling up the tourist region (= destination) being equal to the administrative, political designation.

Provincial trans-boundary concepts are rare. Instead, Central-European nation states' cross-border tourism regions tend to be numerous. (Sadly, they remain often just a political torso, with no added value for the peripheral, border regions.) The positive example of the alpine three-border area of Austria, Italy and Slovenia has been 
elaborated on several occasions (Moritsch 1998, Gosar 2005, ZiMMERMANN 1998). The almost two decades long attempts (1984-1999) to bring this "destination" on the world map of tourist regions through Winter Olympics failed, but the character of a unified tourist region remained. Along with several cross-border tourism products ("Europeus Sine Finibus", "The White Waters of the 3Borders", "The Diner of Three Cultures", etc.) the promotional naming of the area, developed for the two bids to organize the event, namely "Senza Confini" (Without Borders), continues to exist.

\section{The frame}

The answer for the trend of (several) re-defining(s) of Slovenian tourist regions is narrowly linked to the disintegration of Yugoslavia and the political and societal changes (from Communism to democracy and from a central-planning economy to the globalized market economy). Regarding tourism trends, three major time-frames are to be distinguished:

(1) Slovenia as province (= Socialist republic) of Yugoslavia;

(2) Slovenia as a sovereign nation-state (Republic of Slovenia) on the edge of Europe's instability area;

(3) Slovenia as member of the European Union, the Euro-zone and the Schengen space.

Slovenia was within Yugoslavia (until 1991) characterized as a tourism transit area/province. Tourism visits have concentrated on the Mediterranean coast of which Slovenia had just 2.2\%. But the airline (Adria Airways) and travel agencies (including their duty free shops at border crossings), with its headquarters in Slovenia, participated heavily in the Yugoslav tourism economy - by some estimates with close to $43 \%$ (Minalič 1995). According to international visits in 1988, Slovenia was ranked third among the six Yugoslav republics (13.8\% of bed-nights, 1.13 million visitors).

As the disintegration of Yugoslavia turned into a long-lasting military confrontation (Croatia, Bosnia and Herzegovina, Serbia and Montenegro), Slovenia's tourism struggled for survival on the edge of regional instability in the Western Balkans. International visits in 1998 were a mere $23.7 \%$ of the number of tourists registered 10 years before. In 2004, Slovenia was accepted as member of the European Union and NATO, in 2007 the country joined the Schengen Space by eliminating border-control posts towards EU member states (and by strengthening the EU outer border), and - in the same year - the Euro $(€)$ was introduced as the national currency. By 2008 international visits finally overrode the number of tourists from 20 years ago: 1.77 million foreign visitors have been registered, among which Italians (21.2\%), Germans (11.0\%), Austrians (10.9\%) and Croatians (6.0\%) prevailed (Statistični urad Republike Slovenije 2008). 
According to Cigale (2010), the reason to visit Slovenian touristic regions, resorts and municipalities is highly linked to (1) the outstanding recognition of the resort/region, (2) the accessibility of the place, (3) the major highway network, and (4) the touristic product (which is within the sphere of traditional tourist interest). In this sense, the following types of municipalities are ranked according to foreign tourist visits: (1) mountain resorts, (2) Ljubljana, the capital, (3) non-specified touristic resorts, (4) seaside resorts, (5) health resorts, (6) other localities (STATISTIČNI URAd REPUBLiKe SloveniJe 2008). In relation to this fact, we can conclude that Slovenia is mostly known internationally by its mountainous (alpine) environments (see Figure 1). If we add domestic tourism travels, mountainous environments would still prevail, immediately followed by health and seaside resorts (Table 2).

Table 2: Tourist arrivals and overnight stays by types of tourist resorts (in 1,000)

\begin{tabular}{|l|r|r|r|r|r|r|r|r|r|}
\hline \multicolumn{1}{|c|}{ Resort type } & & \multicolumn{2}{c|}{1998} & \multicolumn{2}{c|}{2002} & \multicolumn{2}{c|}{2006} & \multicolumn{2}{c|}{2008} \\
\hline & All & Visits & Stays * & Visit & Stays* & Visit & Stays * & Visit & Stays* \\
\hline Mountain resorts & & 441 & 1,443 & 605 & 1,824 & 607 & 1,790 & 663 & 1,947 \\
\hline Ljubljana, the capital & & 141 & 313 & 214 & 437 & 351 & 636 & 372 & 707 \\
\hline Non-specified resorts & & 265 & 532 & 372 & 798 & 380 & 765 & 434 & 895 \\
\hline Seaside resorts & & 370 & 1,663 & 520 & 2,010 & 523 & 1,925 & 546 & 1,992 \\
\hline Health resorts & & 340 & 1,884 & 501 & 2,359 & 596 & 2,550 & 633 & 2,651 \\
\hline & Intern. & & & & & & & & \\
\hline Mountain resorts & & 185 & 657 & 393 & 1,245 & 423 & 1,276 & 459 & 1,384 \\
\hline Ljubljana, the capital & & 116 & 259 & 195 & 404 & 334 & 608 & 353 & 676 \\
\hline Non-specified resorts & & 166 & 360 & 287 & 594 & 297 & 572 & 342 & 688 \\
\hline Seaside resorts & & 160 & 624 & 280 & 1,035 & 293 & 1,022 & 305 & 1,053 \\
\hline Health resorts & & 93 & 507 & 196 & 850 & 248 & 970 & 266 & 1,018 \\
\hline
\end{tabular}

*bed-nights

(Source: Statistični urad Republike Slovenije 2008)

At this point it should be noted that the division of 64 settlements into six categories of tourism towns - according to resort locality and relief characteristics (mountain, seaside) and/or touristic domain (the capital, health resort, non-specified resort, other localities) - is performed solely at the level of the national statistical office (Statistični urad Republike Slovenije, SURS) and has little to do with the country's geographic divisions, tourism strategies or touristic regionalizations performed by other institutions (see Figure 2). But it is a good indicator of recognition of Slovenia's touristic supply by foreign and domestic tourists. 
Figure 1: Slovenia: Major physiographic regions

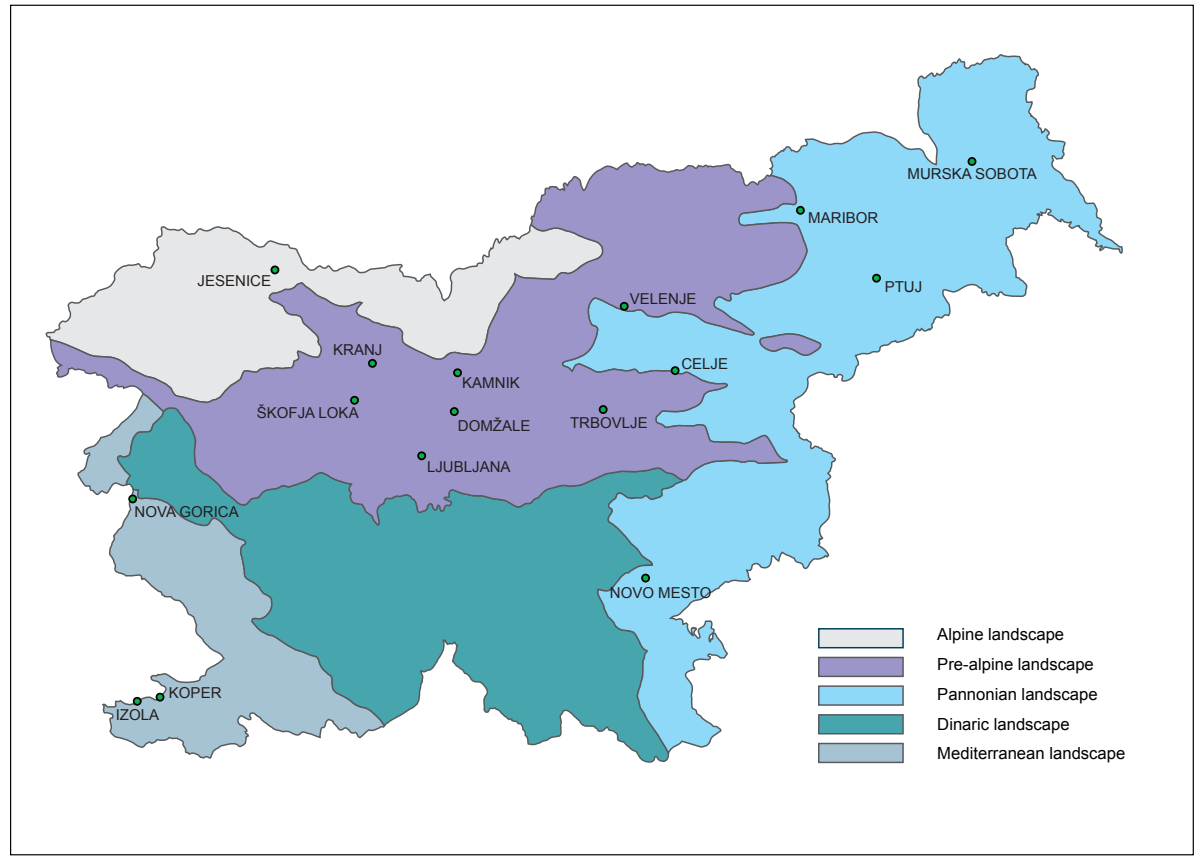

Source: PERKo et al. 1995

Figure 2: Major tourist resorts

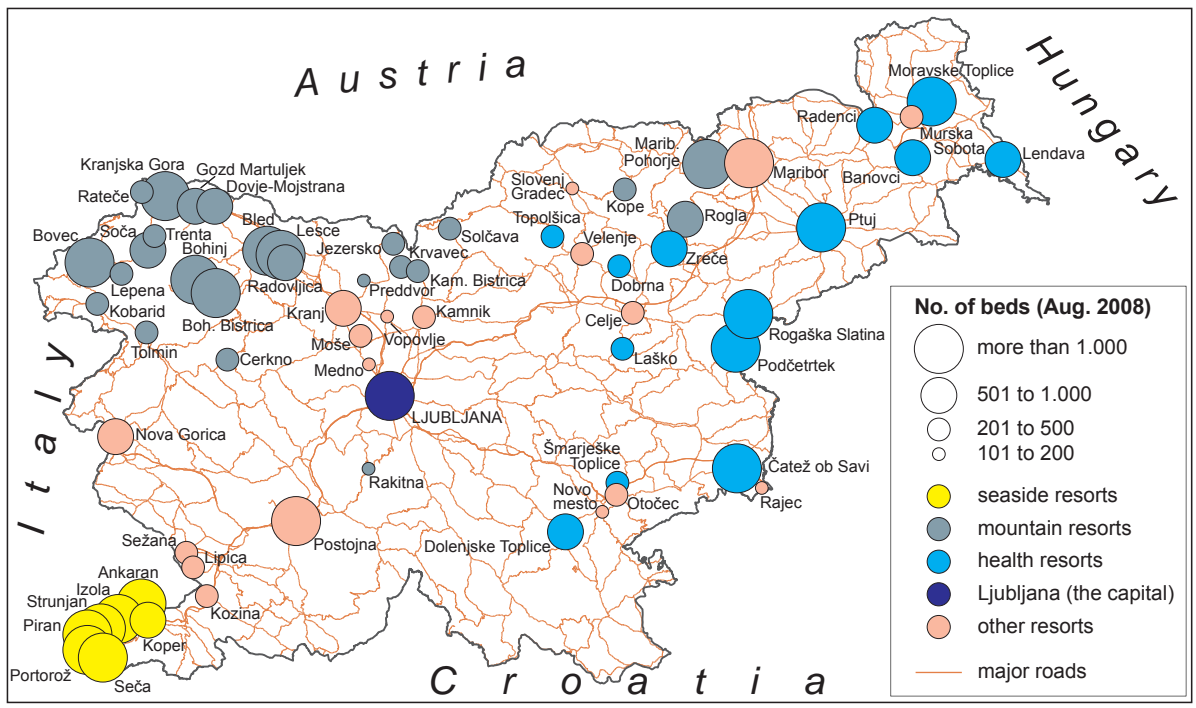

Source: Statistični urad Republike Slovenije 2008 


\section{Tourism strategies and tourism regions}

In Slovenia the first regionalization devoted to/for tourism was written 45 years ago; the next was published about 20 years later. Two have followed. Authors of the first regionalization could be identified as geographers, whereas the subsequent regionalization attempts have all had the imprint of economists. Whereas the beginner produced a regionalization aimed to place Slovenian tourism supply within the Yugoslav frame, the follow-up regionalizations were meant to give orientation to the restructuring tourism sector after the disintegration of the federal state and proclamation of Slovenia's independence. This work from the mid-1990s was accompanied by a precise and knowledgeable strategy, the basic purpose of which was to overcome burdens of the isolation during the continued instability in the Balkan neighborhood.

Registered regionalization attempts for tourism purposes, in conjunction with adequate tourism strategies, to be discussed are:

(1) Slovenia's Touristic Regions, 1965

(2) Tourism Development Strategy, 1993

(3) Slovenian Tourism Strategy, 2002

(4) Slovenian Tourism Development Plan and Directions, 2007

Geography offered substantial groundwork for the strategies and regionalization in progress. In particular, the territory of the state was thoroughly analyzed since independence. Notable are the following publications: the National Atlas of Slovenia (FridL et al. 1995), Slovenia - the Tourist Guide (GoSAR \& JERŠIČ 1999), Relief of Slovenia (Perko \& OrožEn AdAmič 1995), The Township Gazetteer of Slovenia (OrožEN AdAmič et al. 1995), Slovenia: People and Places (Perko \& OrožEn Adamič 1998).

Slovenia had, within the former federation, a substantial autonomy in politics and economy and had even developed its own policy of promotion. The "tourism destination" of the Socialist republic of Slovenia was clearly recognizable within the Yugoslav frame. Slogans like "We, people are tourists" [Turizem smo ljudje] and the slogan with an outstanding geographic touch "Slovenia - on the sunny side of the Alps" [Slovenija - na sončni strani Alp] were established in the 1980s and had had no equivalent in other provinces of Yugoslavia. Since independence in 1991, under the umbrella of the Slovenian Tourism Organization (STO) three slogans have characterized the "touristic destination" of the young nation state: "Slovenia - the Green Piece of Europe" (1994), "Slovenia Invigorates" (2002) and, finally "I Feel SLOVEnia" (2007). "Slovenia - the Green Piece of Europe" indicated the geographic fact of Slovenia's 61\% forestlands; since the slogan was launched in times of the worst military confrontation in the nearby Croatia, some experts speculate on the intended promotional word-play "peace" vs. "piece". 


\subsection{Slovenia's Touristic Regions (1965)}

Slovenia's territory was subdivided on principles of evaluating natural and cultural heritage sites for tourism purposes in the 1960s. Several authors (ŽAGAR 1976, PlaninA \& MiHALIČ 1985 , JERŠIČ 1978) have challenged the initial regionalization by KOKOLE (1965), but not one single author questioned the initial four geographic regions as major "tourist destinations": the European (south-eastern) Alps, the Pannonian/Danubian flatlands and hills, the karstic ridge of the Dinaric Alps, and the Mediterranean coastal zone (see Figure 3). Basic regionalization criteria aimed at attracting tourists were based on natural appearance and character. Physical geography was the lead segment of regionalization. Tourism destinations have been formed accordingly (KoKOLE 1965):

- Alpine Slovenia ["Visokogorje"]

○ Julian Alps [Julijske Alpe] and western Karawanken [Karavanke]

- Eastern Karawanken and Kamnik-Savinja Alps [Kamniške in Savinjske Alpe]

- Pre-Alpine Slovenia [“Predalpski svet"]

- Breginj nook

- Cerkno and Škofja loka highlands

- Ljubljana basin

- Posavje highlands

- Celje basin

○ Podravlje highlands and Pohorje

- Dinaric karst ["Dinarsko-kraško ozemlje"]

○ Karstic plains

- Suha krajina

- Pivka

- Brkini and valleys of Podgrad

- Vipava valley

○ Kras

- Pannonian/Danubian edge [„Panonsko obrobje”]

- Drava lowlands and hills

- Slovenske gorice

- Mura lowlands and Goričko

- Koper seacoast ["Koprsko primorje"]

- Coastal (Adriatic) plains

○ Istria's hilly hinterland [Šavrini]. 
Figure 3: Slovenia: Major tourism regions

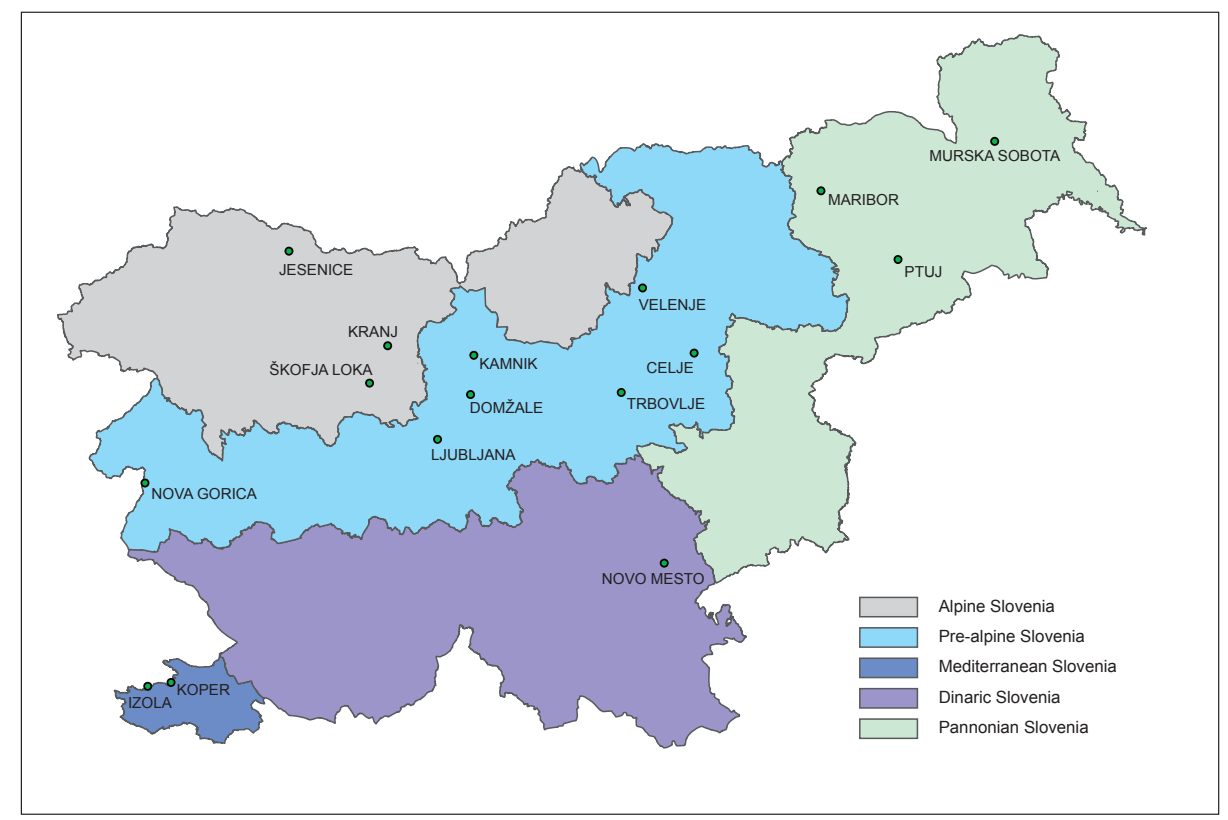

Source: KoKOLE 1965

\subsection{Tourism Development Strategy (1993)}

Slovenia's independence called for the re-drawing of tourism policies. The nation state's border in the East and South, towards Croatia, suddenly eliminated the once very lively exchange of knowledge, services, products and financial transactions of the tourism sector of the economy within Yugoslavia. At the same time, it separated for several years areas of military confrontation from the peaceful part of Europe (with the exception of the 10-day war - June/July 1991 - on Slovenian territory). The geopolitical situation initiated the first tourism strategy ever developed for the territory of Slovenia (SIRŠE et al. 1993, SIRŠE 1995). This initial development strategy distinguished between five "tourism subjects" (see Figure 4):

(1) The Coast and the Karst,

(2) The Mountains and Lakes

(3) The Natural Health Resorts,

(4) The Rural Countryside,

(5) The Historic Towns. 
Likewise, the strategy identified several "tourism products" ["turistični proizvodi"] - like biking, skiing, gambling, etc. The strategy warns readers that "tourism subjects" ["turistična področja"] should not be mixed up with "tourism regions" [turistična območja] - despite the fact that some of the naming has geographic connotation. "Tourism subjects" are namely, according to the authors, spheres of activity and should be perceived as destinations in a broader sense of understanding. Within named spheres of activity, initiation of specific tourism products could take place - namely, according to natural and cultural features (= heritage) of the related geographic area.

It must be noted that the geopolitical situation and this strategy of the 1990s, and to some extent related regionalization, in the initiation stage gave wings to the "watering places", mineral and thermal resorts of Slovenia. Tourist visits in "watering places" doubled: in $198817.5 \%$ and in $200834.1 \%$ of all bed-nights registered have been made in health resorts (HORvat 2010).

Figure 4: Slovenia: Tourism regions according to Tourism Development Strategy

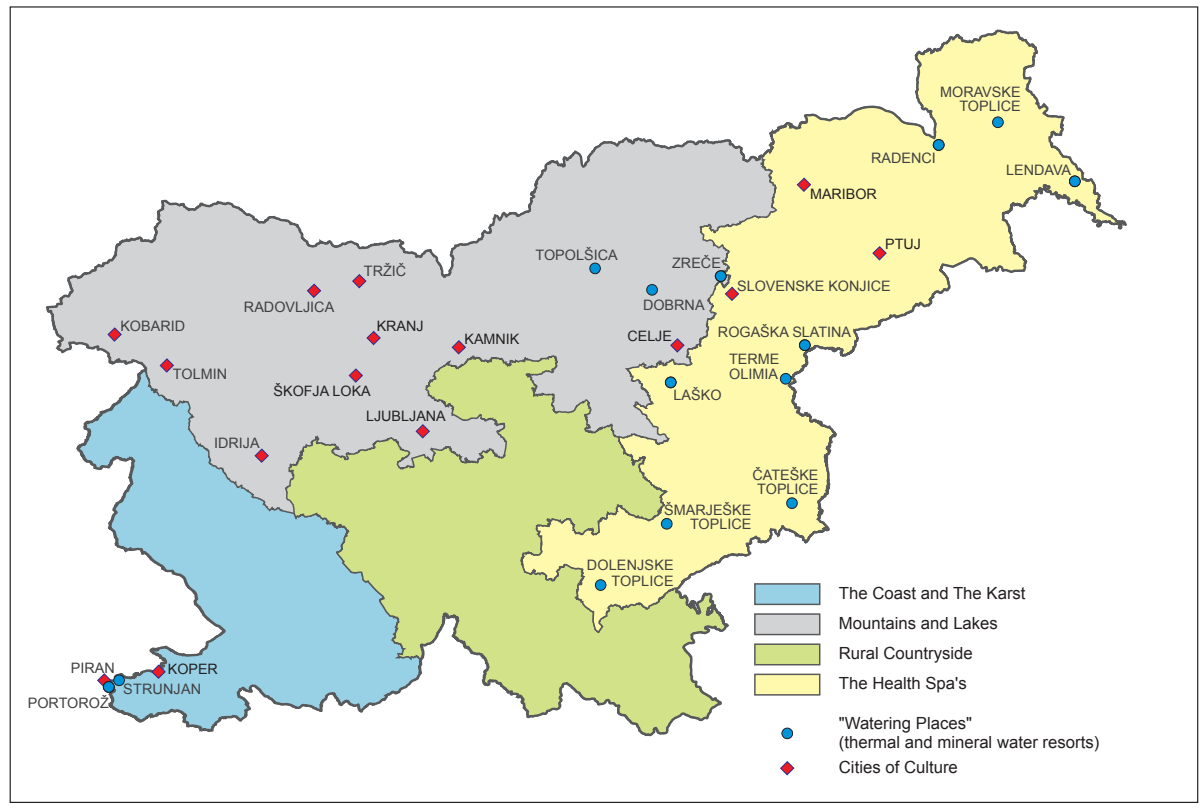

Source: SIRŠE et al. 1993

\subsection{Strategy of the Slovenian Tourism (2002)}

At the dawn of the $21^{\text {st }}$ century, the first move to break the rule of identifying "touristic regions" with geographic setting was made by an economist, whose basic idea was to subdivide Slovenia by its leading "brand-name" tourism destinations 
["blagovne znamke"] - like Portorož/Portorose, Kranjska Gora, Bled, Radenci, Nova Gorica, Ljubljana, etc. - and to point out the importance of the touristic experiences, adventures and entertainment in the contemporary tourism economy (KovAČ 2002). In accordance with this idea, KovAČ put Slovenia under the umbrella of 32 Local Tourism Organizations (LTO, now RDO - Regional Destination Organization) - as suggested in the previous strategy - and placed their headquarters in leading tourist resorts (see Figure 5).

Further, Kovač's strategy initiated tourism research beyond the classical 3S (sun, sand and sea) segment. In accordance with directions set above, along with his 3A (activity and adventure tourism), 3E (rural, responsible and eco-tourism) and 3D (experience and entertainment tourism) he foresaw (just) 3 major geographic spheres "the Sunny Alps", "the Green Mediterranean" and the "Mysterious Karst" worthwhile to promote.

To reach the goal set by Kovač, the Slovenian Tourist Board (STO) accepted the proposal of Imago Slovenia, a consultant firm, to switch its promotional activity from the slogan "Slovenia - The Green Piece of Europe" to "Slovenia Invigorates" and to oversee six promotional segments: "Invigorate your Senses", "Invigorate your Imagination", "Invigorate your Passion", "Invigorate your Body", "Invigorate your Soul”, "Invigorate your Drive" (STO 2004). Geography was moved to the periphery of interest, while the visitor's motives have been put into the foreground of advertisement. Micro-

Figure 5: Slovenia: Casino' Resorts and its regional development area, 2002

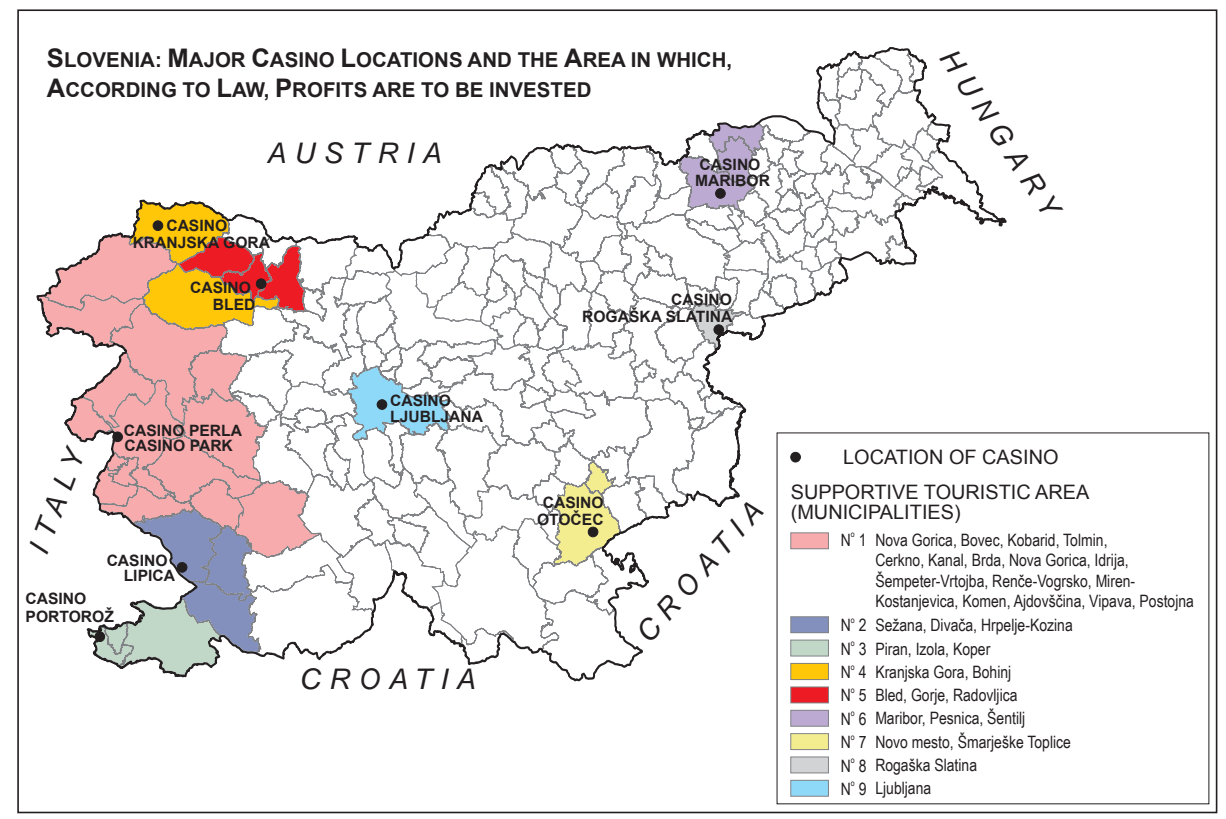


centers of tourism (most often well-known resorts) responsible for the development of a larger tourist region were created. According to law, even gaming enterprises have had their own share of responsibility for the region of their existence.

\subsection{Development plan and directions of Slovenian tourism (2006)}

After Slovenia's inclusion in EU political and financial structures, discussion flamed up within the tourism sector of the economy about the relatively small scale of the nation state's space. The fact that in transit towards Croatia millions of tourists remain on four lane highways and crisscross Slovenia in a couple of hours, without being acquainted with the country's specifics, produced the idea of re-routing tourists off highways. The product "Byways are More Attractive than Highways" along with the phrase "Let's take the next exit" were born. Diverse geographic regions now have intermingled with each other in 6 north-south/south-north highway (better: byway) directions. New "subjects of tourism" and tourism regions have been created. The following touristic regions, based on geographic, historic and cultural heritage have set foot (STO 2005) (see Figure 6):

- Emerald Route (from the sources of the Soča River to innumerable green treasures)

- Wind Route (to the mysterious Karst and the Adriatic Sea)

- Amber Route (on the trail of our ancestors)

- Sun Route (through the warm region of wine and healing waters)

- Peddler Route (from all corners of the world to the white birches)

- Gold horn Route (with a view of Alps and lakes)

In 2006 researchers at Turistica - College of Tourism, Portorož/Portorose (University of Primorska) concluded that efforts to recognize the "destination Slovenia" have not been sufficient and that the existent tourism strategy needs to be enriched with changes in the supply-side of the economy. In their strategy they have pointed out that the exclusive geostrategic position of the nation state can be a burden and opportunity at the same time. The gateway character of the country could be linked to the European cores of tourism (Venice [Venezia], Salzburg, Vienna [Wien], ...), to meetings and exhibits of particular branches, and at the same time to the promotion of specific features of Slovenia (even to tourists in transit). Entertainment, including casinos and wellness programs, in particular on 87 mineral and thermal water locations, should become the identity mark of Slovenia. Tourism products must be linked to already established attractions - like to thematic paths and biking routes, as well as to enology 
tourism and vine routes. The supply side of tourism should be (re-)arranged to the expectation of the 3 leading cultures visiting $(50 \%+)$ : the Italians, the Germans and the Austrians (URAN \& OvSENIK 2006).

Figure 6: Slovenia: Tourism regions according to tourism product "Byways are More Attractive than Highways"

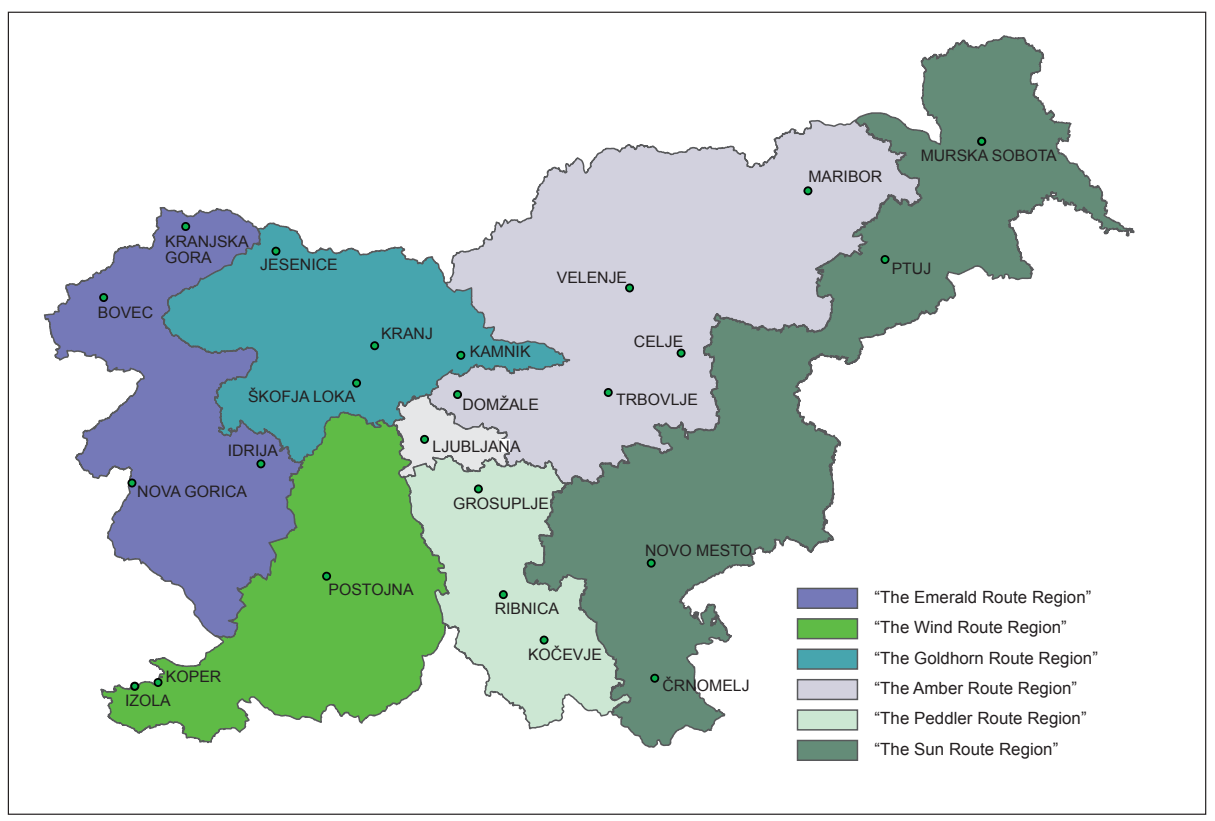

Source: STO 2005

\subsection{Tourism's diverse contemporary regionalization}

In the follow-up implementation of the above discussed strategy by the Slovenian Tourist Board's development plans and directions ["Razvojni načrt in usmeritve slovenskega turizma"] tourism products have become the lead element in tourism promotion and in the creation of contemporary touristic regions. Geography has been regarded only as a general environmental factor to be considered and partly, on a small scale in specific socially/historically related contexts, for example in conjunction with gastro- and enological features (= products).

Authors of the 2006 tourism strategy implementation (VESENJAK \& RAVNIKAR 2007) have deliberated on two issues:
(A) the national tourism product ("Slovenia 4U")
(B) the regional tourism products ("Slovenia Diverse") 
Within frame A (national tourism product) nine sets of activity spheres (not to be identified with any geographic macro-region) have been identified:

o "Slovenia Adventure" - activity rich leisure

- "Slovenia Nature" - countryside holidays

- "Slovenia Culture" - town and country experience

- "Slovenia Culinary" - food and wine tasting

- "Slovenia Balance" - health and wellness programs

o "Slovenia Meetings" - business travels

- "Slovenia Life" - gaming and gambling

- "Slovenia Prestige" - special event holidays

○ "Young People's Slovenia" - youth tourism

Within frame B, regions are to be distinguished on the product bases. The gastronomy tourism product, for example, identifies 24 regions (see Figure 7). Every single region's typical dish is described and locations of taste advertised - like for example for region 17 - the "Culinary Region of Rovte, Idrija and Cerkno": Typical dishes of the region (idrijski žlikrofi, smukavc, zelševka, etc.) may be also tasted in the following restaurants: Kmečki hram Fortuna and Kos in Idrija and in Kendov dvorec hotel in Sp. Idrija that was built in the $14^{\text {th }}$ century; Kendov dvorec in Sp. Idriji, full of relics of the past, continues with preserving the rich culinary tradition in the way how the ancient local dishes are being prepared in the "nouvelle cuisine" style. (STO 2009)

\section{Figure 7: Slovenia: Culinary regions}

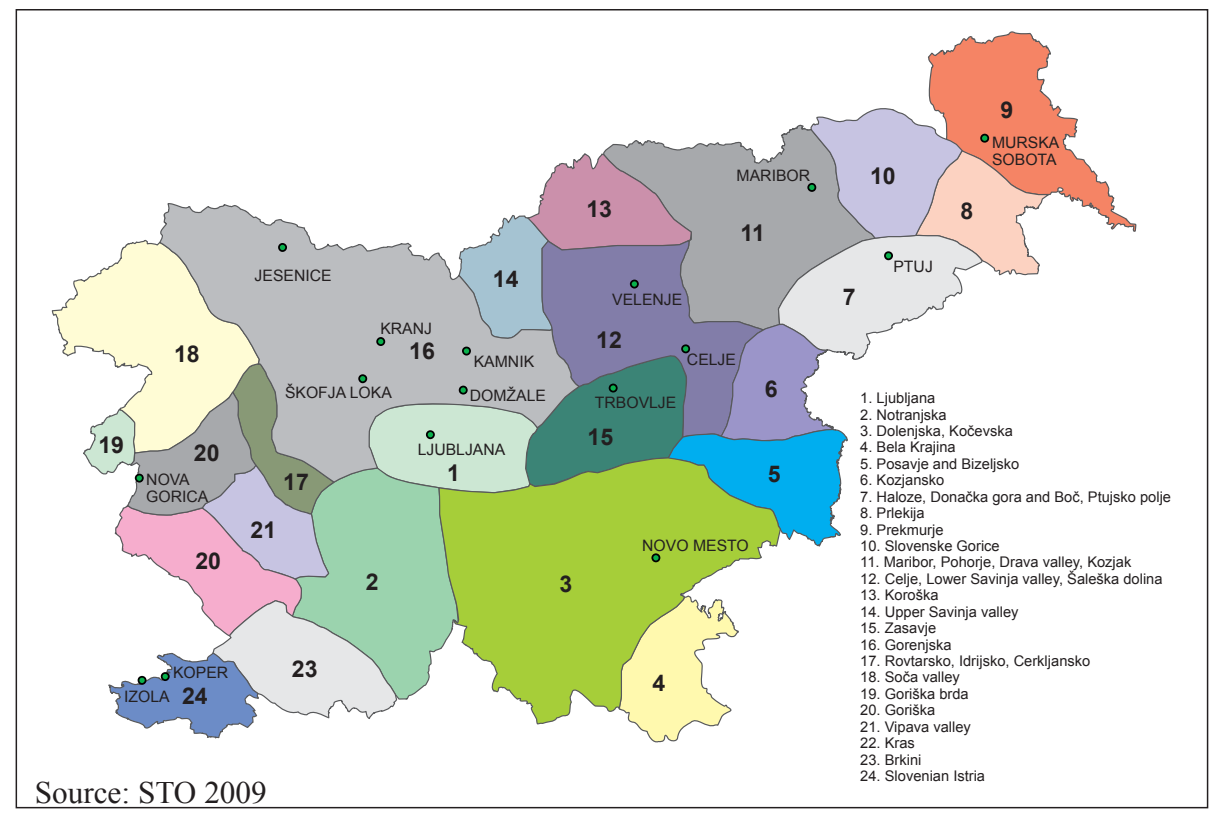


Further deliberations among authors of the tourism strategy No. 4 (2006) resulted in the conviction that some tourism products could be promoted and experienced only on a geographic micro-scale, where certain historic environments, traditions and social/ cultural knowledge exist. The forthcoming Slovenian tourism strategy No. 5 (2012) would again put the importance of the geographic frame forward. Namely, the Official Gazette of the Republic of Slovenia just recently stated that "the tourist regions are geographically rounded up areas of one or more municipalities which offer defined touristic services and/or tourism products in their entirety and are therefore becoming travel destinations of tourists." (Republika Slovenija 2011).

According to diverse sources, 15 to 23 tourism regions (Slovenia Info 2010, Kos GRABNAR 2010) have been identified (from West to East; the endonyms of regions are in brackets, see Figure 8): The Adriatic Coast [Obala]; The Adriatic Karst [Primorski Kras]; The Karst of Inner Carniola [Notranjski Kras]; Gorizia and the Vipava Valley [Goriška-Vipavska]; The Isonzo Valley [Posočje]; The Ribnica-Kočevje area [RibniškoKočevsko]; Ljubljana and surroundings [Ljubljana z okolico]; The area of Škofja Loka [Škofjeloško]; Kranj and surroundings [Kranj z okolico]; The Upper Sava Valley [Zgornje Savsko]; Bela krajina; Central Lower Carniola [Osrednja Dolenjska]; The Mid-Sava Valley [Zasavje]; The Lower Sava Valley [Posavje]; The Sotla Valley [Obsotelje]; Celje and surroundings [Celje z okolico]; The Upper Savinja Valley [Zgornjesavinjsko]; The Lower Drava Valley [Spodnje Podravje]; The Dravinja Valley [Dravinjsko]; Carinthia [Koroška]; Maribor and surroundings [Maribor z okolico]; The Hills of Prlekija [Prlekija]; The Lowlands and Hills of Prekmurje [Prekmurje].

Figure 8: Slovenia: Regions of typical touristic products

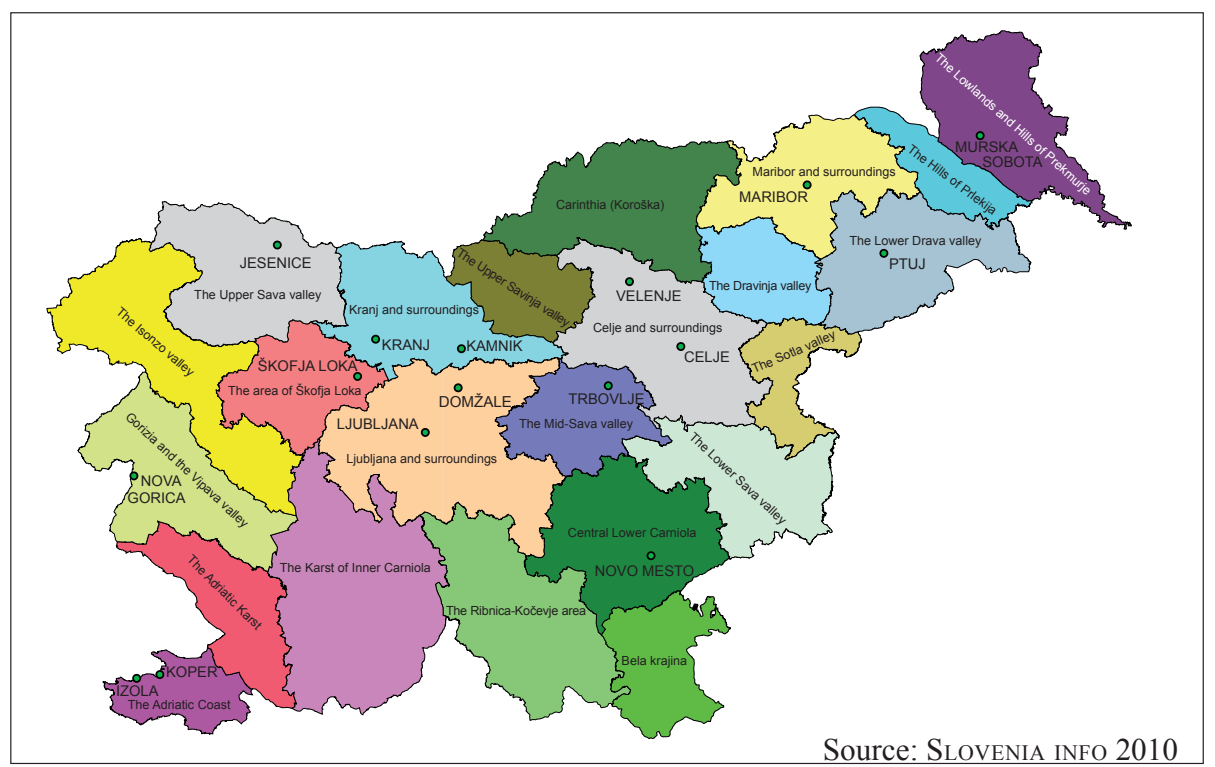




\section{Conclusion}

Slovenia is among some rare countries of the world where national tourism development strategies are produced and refurbished. Since publication of the first regionalization for tourism purposes in 1965 (within Yugoslavia), Slovenian researchers and tourism managers have developed several strategies. Some just placed directions for the proper identity of Slovenia as tourist destination; others have considered heritage as "tourism subjects" on nation state's micro-scale level and produced adequate regionalizations.

The first strategy and regionalization, made for the young nation state in 1993, had to consider the consequences of the disintegration of Yugoslavia and had to pin-point tourism products which had potentials in this, naturally and culturally very diverse European country. The growth in visits to the "watering places" of Slovenia has, for example, proven right to the development directives of the strategy.

The physical landscape and character, and even the natural and cultural heritage elements are playing an increasingly weak role in the definition of contemporary touristic regions. Tourism products promoting experience, entertainment and adventure, as well as human-made attractions (including cultural events and events based on tradition), are the primary decision maker(s) in contemporary attempts to characterize specific macro-, meso- or micro-regions of tourism.

\section{Bibliography}

Butler R., Aramberi J. (2005), Tourism Development: Issues for a Vulnerable Industry: Aspects of Tourism. Chichester, Chanel View Publ.

CIgAle D. (2010), Značilnosti turističnega oiska slovenskih občin glede na državni izvor turistov. In: Geografski vestnik - Geographical Bulletin, 82, 2, pp. 9-24.

Fridl J., Kladnik D., Orožen Adamič M., Perko D., Zupančıč J. (eds.) (1995), Geografski atlas Slovenije. Ljubljana, Geografski inštitut Antona Melika ZRC SAZU.

Fridl J., Perko D. (2006), Slovenija. Ljubljana, Rokus.

Gosar A. (2005), The Cross-Border Bricklaying Concept in the Alpen-Adria Region. In: Tourism Analyses, 10, 1, pp. 65-78. (http://www.citeulike.org/journals)

Gosar A., Jeršřč M. (1999), Slovenia - the Tourist Guide. Ljubljana, Mladinska knjiga.

Horvat U. (2010), Health resorts and their importance for the development of less developed areas in Slovenia. In: Revija za geografijo, 5, 1, pp. 147-159.

JERŠǏč M. (1978), Bewertung des Naturraumpotentials für den Gesellschaftsbedarf an Hand von Beispielen aus Slowenien. In: PAK, M. (ed.), Socialnogeografski problemi obmestnih in obmejnih območij (= Geographica Slovenica, 8). Ljubljana, pp. 159-163. 
Jordan P., Schappelwein K. et al. (1999), International Tourism Attractions in Central and Southeastern Europe [1:3,000,000]. In: JoRDAN P. (ed.), Atlas of Eastern and Southeastern Europe. Stuttgart, Borntraeger.

KокоLE V. (1965), Slovenske pokrajine in turizem. In: Geografski obzornik, XII/1-2, XIII/1-2. Ljubljana, Geografsko društvo Slovenije.

Kos Grabnar J. (2010), Predlog členitve Slovenije na turistične pokrajine in območja. In: Delovni zvezek SDE, 10. (http://www.sdeval.si/attachements/184_SDEDZ_Turist_regionali\%20 (14.05.2009)

Kovač B. et al. (2002), Strategija slovenskega turizma 2002-2006. Ljubljana, Ministerstvo za gospodarstvo, Vlada Republike Slovenije.

Mihalič T. (1995), Tourism and Warfare: the Case of Slovenia. In: Pizam A., Mansfeld Y. (eds.), Tourism, Crime and International Security Issues, pp. 231-246. Chichester, John Wiley \& Sons.

Moritsch A. (1998), Ursachen und Folgen der politischen Teilung in den Alpen - das Beispiel Dreiländereck $=$ The Causes and Consequences of Border Settings in the Alps - the Case of the "Dreilaendereck/Tre Confini/Tromeja". In: Dela, 13, pp. 189-200.

Orožen Adamič M., Perko D., Kladnik D. (1995), Krajevni leksikon Slovenije. Portorož, DZS.

Perko D., OrožEn Adamič M. (1995), Relief Slovenije. Ljubljana, Znanstveno raziskovalni center SAZU.

Perko D., Orožen Adamič M. (1998), Slovenija: pokrajine in ljudje. Ljubljana, Verlag.

Planina J., Mihalič T. (1985), Razvoj in dejavniki turističnega povpraševanja. Ljubljana, Inštitut za ekonomska raziskovanja.

RePublika SloveniJa (ed.) (2011), Zakon o spodbujanju razvoj turizma (ZSRT). In: Uradni list, ULRS 2011, 2. (http://www.uradni-list.si/1/objava.jsp?urlid=20042\&stevilka=73)

SIRšE J. (1995), The New Strategy for the Development of Tourism in Slovenia. In: Revue Tourism, 50, 2, pp. 18-22.

SiršE J., Stroj-VRtačnik I., Pobega N. (1993), Strategija razvoja slovenskega turizma. Ljubljana, IER - Inštitut za ekonomska raziskovanja.

SLOVENIA INFO (ed.) (2010), Turistične destinacije (http://www.slovenia.info/si/turisticne-destinacije.htm?destinacije $=0 \& \operatorname{lng}=1$ )

Slovensko Društvo Evalvatorjev (ed.) (2010), Predlog členitve na turistične pokrajine in območja. http://www.sdeval.si/attachements/184_SDEDZ_Turist_regionali\%20 (14.05.2009)

Statistični urad Republike Slovenije (ed.) (2008), Statistical Yearbook: Tourism: Tourist Arrivals and Overnight Stays by Types of Tourist Resorts. Ljubljana, pp. 429-430.

Slovenian Tourist Board (STO) (ed.) (2004), Slovenija poživlja! Slovenia invigorates! Slowenien belebt! Tržna kampanija ob vstopu v EU ( http://www.slovenia.info/pictures\% 5Cpress\%5Catachments_1\%5C2004\%5C06-07_TURIZEM_397.pdf)

SLovenian Tourist Board (STO) (ed.) (2005), Byways are more attractive than highways. NEXTEXIT. Ljubljana (promotional material). Ljubljana.

Slovenian Tourist Board (STO) (ed.) (2007), Strategija trženja slovenskega turizma. Ljubljana, Hosting svetovanje d.o.o.

Slovenian Tourist Board (STO) (ed.) (2009), Culinary Regions of Slovenia (Janez Bogataj) (http://en.slovenskifestivalvin.si/radost/winegastronomy/about-gastronomy/culinaryregions/) 
Uran M., OvsenIK R. (2006), Razvojni načrt in usmeritve slovenskega turizma 2007-2011. In: UP Turistica, Portorož.

Vesenjak P., Ravnikar D. (2007), Strategija trženja slovenskega turizma 2007-2011. Ljubljana, Slovenska turistična organizacija.

ZimMERMANN F.M. (1998), Das europäische Raumentwicklungskonzept als Grundlage für grenzüberschreitende Kooperationen $=$ The European Concept of Spatial Development as the Base for Transborder Cooperations. In: Dela, 13, pp. 225-235.

ŽAGAR M. (1976), Turistični potenciali Slovenije. In: Geografski obzornik, 23, 1-2, pp. 3-14. 